\title{
PENGETAHUAN DAN PEMAHAMAN ATURAN PERPAJAKAN, KUALITAS PELAYANAN DAN PERSEPSI ATAS EFEKTIVITAS SISTEM PERPAJAKAN TERHADAP KEMAUAN MEMBAYAR PAJAK DENGAN KESADARAN MEMBAYAR PAJAK SEBAGAI VARIABEL INTERVENING
}

\author{
Zainuddin ${ }^{1}$ \\ ${ }^{1}$ Dosen Universitas Khairun, Ternate
}

\begin{abstract}
This research aimed to find factors that affect of awareness to pay taxes, tax paying knowledge and understanding of taxation laws, service quality and a good perception of the effectiveness of the tax system to taxpayers willingness to pay taxes, case study on individual taxpayers who perform as a freelancer that registered at KPP Pratama Ternate. Data was collected by using a random sampling toward 86 respondents. The data was analyzed by using the SPSS program to test whether the model used in this study quite appropriate as the model analyzed. Then the regression analysis was used to test the relationship between the variables above. The results of this research indicated that knowledge and understanding of taxation law, service quality, and a good perception of the effectiveness of the taxation system had a significant effect toward willingness to pay taxes. Also awareness to pay taxes had a significant effect toward willingness to pay taxes.
\end{abstract}

Keywords: Willingness to Pay Taxes, Pay Taxes Awareness, Knowledge and Understanding of Taxpayers, a Good Perception of the Effectiveness of the Taxation System, Service Quality

\begin{abstract}
ABSTRAK
Penelitian ini ditujukan untuk mengetahui pengaruh kesadaran membayar pajak, pengetahuan dan pemahaman peraturan perpajakan, kualitas pelayanan dan persepsi atas efektivitas sistem perpajakan terhadap kemauan membayar pajak yang mana diuji pada wajib pajak orang pribadi dengan pekerjaan bebas yang terdaftar di KPP Pratama Ternate. Data dikumpulkan dengan menggunakan metode random sampling yaitu sebanyak 86 responden. Data dianalisis reliabilitas dan validitasnya dengan menggunakan SPSS sebagai program untuk menguji apakah model yang digunakan dalam penelitian ini cukup tepat sebagai model yang dianalisis. Selanjutnya, analisis regresi berganda digunakan untuk menguji hubungan variabel-variabel di atas. Hasil penelitian menunjukkan bahwa variabel pengetahuan dan pemahaman akan peraturan perpajakan, kualitas pelayanan dan persepsi atas efektivitas perpajakan berpengaruh signifikan terhadap kesadaran membayar pajak. Kesadaran membayar pajak berpengaruh signifikan terhadap kemauan membayar pajak.
\end{abstract}

Kata kunci: Pengetahuan dan Pemahaman Peraturan Perpajakan, Kualitas Pelayanan, Persepsi Efektivitas Sistem Perpajakan, Kesadaran Membayar Pajak, Kemauan Membayar Pajak

\section{Jurnal Akun Nabelo: Jurnal Akuntansi Netral, Akuntabel, Objektif Volume 1/Nomor 1/Juli 2018 Jurusan Akuntansi FE-Universitas Tadulako}

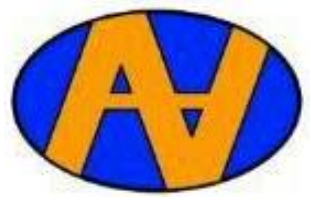




\section{A. PENDAHULUAN}

Pajak sangatlah penting dalam penerimaan negara, bahkan dalam Anggaran Pendapatan Belanja Negara (APBN) pajak merupakan sumber pendapatan terbesar. Negara Indonesia sangat bergantung kepada pajak karena saat ini sekitar $70 \%$ APBN Indonesia dibiayai oleh pajak. Hal ini menunjukkan bahwa peran pajak dalam membiayai APBN semakin besar. Sumber dana yang berasal dari pajak tersebut digunakan oleh pemerintah untuk membiayai pengeluaran negara yaitu pengeluaran rutin dan pengeluaran pembangunan. Begitu besarnya peran pajak dalam APBN maka usaha untuk meningkatkan penerimaan pajak terus dilakukan oleh pemerintah yang dalam hal ini merupakan tugas Direktorat Jenderal Pajak (DJP). Berbagai upaya dilakukan DJP agar penerimaan pajak maksimal, antara lain adalah dengan ekstensifikasi dan intensifikasi pajak. Hal tersebut dilakukan dengan cara perluasan subjek dan objek pajak, dengan menjaring wajib pajak baru. Usaha memaksimalkan penerimaan pajak tidak dapat hanya mengandalkan peran dari Direktorat Jenderal Pajak maupun petugas pajak, tetapi dibutuhkan juga peran aktif dari wajib pajak itu sendiri. Perubahan sistem perpajakan dari
Official Assessment menjadi Self Assessment, memberikan kepercayaan wajib pajak untuk mendaftar, menghitung, membayar dan melaporkan kewajiban perpajakannya sendiri. Hal ini menjadikan kepatuhan dan kesadaran wajib pajak menjadi faktor yang sangat penting dalam hal untuk mencapai keberhasilan penerimaan perpajakan (Widayati dan Nurlis, 2010).

Pemungutan pajak memang bukan suatu pekerjaan yang mudah, disamping peran aktif dari petugas perpajakan, juga dituntut kemauan dari para wajib pajak dalam membayar pajak, khususnya bagi WPOP yang melakukan pekerjaan bebas. Usaha ekstensifikasi dan intensifikasi pajak merupakan aksi yang telah direncanakan oleh Direktorat Jenderal Pajak dalam rangka meningkatkan penerimaan pajak, yaitu dengan memperluas subjek dan objek pajak atau dengan menjaring wajib pajak baru. Sebenarnya masih banyak wajib pajak potensial yang belum terdaftar sebagai wajib pajak aktual. Ketidaktaatan dalam membayar pajak tidak hanya terjadi pada lapisan pengusaha saja tetapi telah menjadi rahasia umum bahwa para pekerja profesional lainnya juga tidak taat untuk membayar pajak (Widayati dan Nurlis, 2010).

Tabel 1

Tingkat Kepatuhan Pajak di KotaTernate

\begin{tabular}{|c|c|c|c|}
\hline Tahun & $\begin{array}{c}\text { Jumlah Wajib Pajak } \\
\text { Orang Pribadi }\end{array}$ & $\begin{array}{c}\text { SPT Yang } \\
\text { dilaporkan }\end{array}$ & $\begin{array}{c}\text { Tingkat } \\
\text { Kepatuhan }\end{array}$ \\
\hline 2010 & 5166 & 470 & $9.10 \%$ \\
\hline 2011 & 5717 & 502 & $8.78 \%$ \\
\hline 2012 & 6269 & 505 & $8.06 \%$ \\
\hline 2013 & 6824 & 635 & $9.31 \%$ \\
\hline 2014 & 7951 & 588 & $7.40 \%$ \\
\hline
\end{tabular}

Sumber: KPP Pratama Ternate, 2017

Dari Tabel 1 di atas dapat dilihat bahwa selama lima tahun terakhir yaitu tahun 20102014,wajib pajak orang pribadi yang terdaftar di KPP Pratama Ternate meningkat dari tahun ke tahun. Namun tingkat kepatuhan wajib pajak di Ternate cenderung menurun. Bila setiap wajib pajak sadar akan kewajibannya untuk membayar pajak, tentunya penerimaan negara atas pajak akan terus meningkat, bukan berkurang, sebab jumlah wajib pajak potensial 
cenderung semakin bertambah setiap tahun.

Kesadaran wajib pajak dalam membayar pajak dipengaruhi oleh beberapa faktor. Pengetahuan dan pemahaman akan peraturan perpajakan sangat penting. Sejak terbitnya Undang-Undang Nomor 6 Tahun 1983, yang kemudian diubah dengan UU No. 28 Tahun 2007 tentang Ketentuan Umum dan Tata Cara Perpajakan dikenal istilah Self Assessment System, dengan dianutnya sistem ini maka selain bergantung pada kesadaran dan kejujuran wajib pajak, pengetahuan teknis perpajakan yang memadai juga memegang peran penting, agar wajib pajak dapat melaksanakan kewajiban perpajakannya dengan baik dan benar. Faktor lain yang mempengaruhi kemauan membayar pajak adalah adanya pelayanan fiskus yang berkualitas. Pelayanan fiskus yang berkualitas adalah fiskus yang memberikan informasi yang akurat tentang halhal yang berkaitan dengan pajak dan tata cara perhitungannya serta tidak melakukan penggelapan pajak ataupun tindakan lain yang tidak sesuai dengan peraturan dan SOP yang berlaku. Munculnya oknum seperti Gayus, Dhana Widyatmika dan banyak petugas pajak lainnya membuat keyakinan wajib pajak atas kinerja pelayan fiskus berkurang sehingga wajib pajak tidak mau membayar pajak karena takut uangnya digelapkan, bukan untuk pembangunan negara, atau adanya biaya tambahan yang dipungut oleh fiskus (Nugroho, 2012). Faktor lain adalah persepsi wajib pajak atas efektivitas sistem perpajakan. Direktorat Jenderal Pajak membuat sistem pendukung yang diharapkan dapat memudahkan wajib pajak dalam membayar dan melaporkan kewajiban pajaknya yaitu adanya $e$ filing, e-SPT, e-NPWP, drop box dan e-banking. Wajib pajak mempunyai persepsi sendiri tentang sistemsistem yang dimiliki oleh Direktorat Jenderal Pajak. Dengan adanya sistem ini, persepsi wajib pajak atas efektivitas sistem perpajakan meningkat karena semua sistem tersebut membuat wajib pajak dapat melakukan semua proses pajak tepat waktu dan dapat dilakukan dimana saja sehingga kesadaran wajib pajak meningkat untuk membayar $\mathrm{PPh}$, baik orang pribadi maupun badan.

Penelitian ini mengacu pada penelitian Nugroho (2012) yang dilakukan dengan tujuan untuk mengetahui pengaruh pengetahuan dan pemahaman akan peraturan perpajakan, kualitas pelayanan dan persepsi wajib pajak atas efektivitas sistem perpajakan dengan kesadaran membayar pajak sebagai variabel intervening.

\section{B. TELAAH PUSTAKA}

\section{B.1 Theory of Planned Behavior}

Theory of planned behavior (TPB) menyatakan bahwa selain sikap terhadap tingkah laku dan norma-norma subjektif, individu juga mempertimbangkan kontrol tingkah laku yang dipersepsikannya yaitu kemampuan mereka untuk melakukan tindakan tersebut. Teori ini menyatakan bahwa keputusan untuk menampilkan tingkah laku tertentu adalah proses rasional yang diarahkan pada suatu tujuan tertentu dan mengikuti urut-urutan berpikir. Pilihan tingkah laku dipertimbangkan, konsekuensi dan hasil dari setiap tingkah laku dievaluasi dan dibuat sebuah keputusan apakah akan bertindak atau tidak. Kemudian keputusan itu direfleksikan dalam tujuan tingkah laku, di mana dapat menjadi predictor yang kuat terhadap cara kita akan bertingkah laku dalam situasi yang terjadi (Ajzen (1980) dalam Anangga (2012)). Alasan pemilihan teori ini adalah kemauan untuk membayar pajak terkait dengan persepsi wajib pajak dalam membuat penilaian terhadap pajak itu sendiri. Persepsi seseorang untuk membuat penilaian mengenai sesuatu sangat 
dipengaruhi oleh kondisi yang dialami seseorang tersebut.

\section{B.2 Pemahaman Tentang Perpajakan \\ Pengertian pajak menurut} Undang-Undang Nomor 16 Tahun 2009 tentang Perubahan Keempat Atas Undang-Undang Nomor 6 Tahun 1983 Tentang Ketentuan Umum Perpajakan diisebutkan bahwa pajak adalah kontribusi wajib kepada negara yang terutang oleh orang pribadi atau badan yang bersifat memaksa berdasarkan undang-undang, dengan tidak mendapatkan imbalan secara langsung dan digunakan untuk keperluan negara bagi sebesarbesarnya kemakmuran rakyat.

Wajib Pajak didefinisikan pada Undang-Undang No. 16 tahun 2009 tentang Ketentuan Umum dan Tata Cara Perpajakan Pasal 1 ayat 1 . Wajib Pajak adalah orang pribadi atau badan yang meliputi pembayaran pajak, pemotongan pajak dan pemungut pajak yang mempunyai hak dan kewajiban perpajakan sesuai dengan ketentuan peraturan perundangundangan perpajakan. Yang dimaksud dengan wajib pajak orang pribadi yang melakukan pekerjaan bebas adalah wajib pajak orang pribadi yang memperoleh penghasilan dengan menggunakan keahliannya tanpa adanya ikatan dengan suatu hubungan kerja.

\section{B.3 Kemauan Membayar Pajak}

Konsep kemauan membayar pajak (willingness to pay tax) diartikan suatu nilai yang rela dikontribusikan oleh seseorang (yang ditetapkan dengan peraturan) digunakan untuk membiayai pengeluaran umum negara dengan tidak mendapat jasa timbale (kontraprestasi) secara langsung (Tatiana, 2009). Konsep ini dikembangkan melalui dua subkonsep yaitu, pertama, konsep kemauan untuk membayar, kemauan membayar merupakan suatu nilai di mana seseorang rela untuk membayar, mengorbankan atau menukarkan sesuatu untuk memperoleh barang atau jasa. Kedua, konsep pajak adalah prestasi yang dipaksakan sepihak oleh negara dan terutang kepada pengusaha (menurut norma-norma yang ditetapkan secara umum), tanpa adanya kontraprestasi dan semata-mata digunakan untuk menutup pengeluaran-pengeluaran umum. Sikap moral dalam bentuk keinginan atau kemauan untuk membayar pajak sangat diperlukan dengan mengingat bahwa pajak merupakan suatu kewajiban yang mutlak kepada warga negara, maka hal tersebut perlu bagi pihak pemerintah untuk turut serta dalam meningkatkan rasa kecintaan bernegara sejak dini. Kemauan membayar pajak dalam Theory of Planned Behavior (TPB) pada penelitian ini digunakan untuk mengetahui pengaruh minat berperilaku (behavior intention) terhadap perilaku (behavior). Apabila wajib pajak sudah memiliki minat atau sadar membayar pajak tinggi maka wajib pajak akan mau membayar pajak tepat waktu.

\section{B.4 Kesadaran Membayar Pajak}

Menurut Susanto (2012), kesadaran membayar pajak ini tidak hanya memunculkan sikap patuh, taat dan disiplin semata tetapi diikuti sikap kritis juga. Semakin maju masyarakat dan pemerintahannya, maka semakin tinggi kesadaran membayar pajaknya. Tetapi semakin kritis wajib pajak dalam masalah perpajakan, semakin tinggi juga prasangka negatif. Kesadaran membayar pajak dalam Theory of Planned Behavior (TPB) pada penelitian ini berkaitan dengan kepercayaan berperilaku (behavior belief), dalam kemauan membayar pajak. Karena sebelum melakukan sesuatu individu harus memiliki keyakinan akan hasil yang diperoleh dari perilakunya tersebut, kemudian yang bersangkutan akan memutuskan untuk melakukanya atau tidak. Wajib pajak yang sadar kewajiban perpajakannya akan memiliki keyakinan mengenai 
pentingnya

memenuhi

kewajibannya sebagai wajib pajak.

\section{B.5 Pengetahuan dan Pemahaman Peraturan Perpajakan}

Pengetahuan dan pemahaman akan peraturan perpajakan adalah proses di mana wajib pajak mengetahui tentang perpajakan dan mengaplikasikan pengetahuan itu untuk membayar pajak. Pengetahuan dan pemahaman pertaturan perpajakan yang dimaksud mengerti dan paham tentang ketentuan umum dan tata cara perpajakan (KUP) yang meliputi tentang bagaimana cara menyampaikan Surat Pemberitahuan (SPT), pembayaran, tempat pembayaran, denda dan batas waktu pembayaran atau pelaporan SPT (Resmi, 2011). Pengetahuan dan pemahaman wajib pajak mengenai peraturan perpajakan berkaitan dengan persepsi wajib pajak dalam menentukan perilakunya (perceived control beliefs) dalam kesadaran membayar pajak. Semakin tinggi pengetahuan dan pemahaman wajib pajak, maka wajib pajak dapat menentukan perilakunya dengan lebih baik dan sesuai dengan ketentuan perpajakan. Namun jika wajib pajak tidak memiliki pengetahuan mengenai peraturan dan proses perpajakan, maka wajib pajak tidak dapat menentukan perilakunya dengan tepat.

\section{B.6 Kualitas Pelayanan}

Pelayanan perpajakan dibentuk oleh dimensi kualitas sumber daya manusia (SDM), ketentuan perpajakan dan sistem informasi perpajakan. Standar kualitas pelayanan prima kepada wajib pajak akan terpenuhi bilamana SDM melakukan tugasnya secara profesional, disiplin dan transparan. Dalam kondisi wajib pajak merasa puas atas pelayanan yang diberikan kepadanya, maka mereka cenderung akan melaksanakan kewajiban membayar pajak sesuai dengan ketentuan yang berlaku
(Hardiningsih, 2011). Pelayanan yang diberikan oleh fiskus turut membentuk sikap (atitude) wajib pajak dalam mengikuti proses perpajakan. Semakin baik pelayanan fiskus maka wajib pajak akan memiliki sikap yang positif terhadap proses perpajakan. Namun jika pelayanan fiskus tidak baik, hal itu akan membuat wajib pajak enggan untuk membayar pajak sesuai ketentuan yang berlaku. Petugas pajak dituntut untuk mampu melayani setiap Wajib Pajak dengan baik, sopan santun, memiliki rasa hormat kepada wajib pajak sebagai pelanggan, serta memiliki keahlian dan pengetahuan di bidang pajak yang tentunya akan menunjang kualitas dari pelayanan dari petugas pajak kepada wajib pajak (Nugroho, 2012). Memberikan palayanan yang baik kepada wajib pajak berkaitan dengan kepercayaan-kepercayaan normatif (normative beliefs). Dengan pelayanan yang baik akan mempengaruhi dan memotivasi wajib pajak akan memenuhi kewajibannya untuk membayar pajak karena wajib pajak akan merasa senang dan dimudahkan serta terbantu dalam penyelesaian kewajiban perpajakannya.

\section{B.7 Persepsi atas Efektivitas Sistem Perpajakan}

Widayati dan Nurlis (2010) menyatakan bahwa hal-hal yang mengindikasikan efektivitas sistem perpajakan yang saat ini dapat dirasakan oleh wajib pajak antara lain: (1) adanya sistem pelaporan melalui $e-S P T$ dan $e$-filling sehingga wajib pajak dapat melaporkan pajak secara lebih mudah dan cepat; (2) pembayaran melalui $e$ banking yang memudahkan wajib pajak dapat melakukan pembayaran dimana saja dan kapan saja; (3) penyampaian SPT melalui drop box yang dapat dilakukan di berbagai tempat dan tidak harus di KPP tempat wajib pajak terdaftar; (4) peraturan perpajakan dapat diakses secara lebih cepat melalui internet tanpa 
harus menunggu adanya pemberitahuan dari KPP tempat wajib pajak terdaftar; dan (5) pendaftaran NPWP yang dapat dilakukan secara online melalui $e$ registration dari website pajak yang memudahkan wajib pajak untuk memperoleh NPWP secara lebih cepat. Persepsi atas efektivitas sistem perpajakan berkaitan dengan persepsi wajib pajak dalam menentukan perilakunya (perceived control behavior) terhadap kemauan membayar pajak. Jika wajib pajak merasa sistem perpajakan yang ada adalah terpercaya, handal dan akurat, maka wajib pajak akan memiliki pandangan yang positif untuk sadar membayar pajak. Namun jika sistem perpajakan yang ada tidak memuaskan bagi wajib pajak, maka hal itu dapat turut mempengaruhi kemauan wajib pajak.

\section{B.8 Pengembangan Hipotesis}

B.8.1 Pengaruh Pengetahuan dan Pemahaman tentang Peraturan Perpajakan terhadap Kemauan Membayar Pajak

Pemahaman dan pengetahuan peraturan perpajakan dalam Theory of Planned Behavior (TPB) berkaitan dengan menentukan perilaku (perceived control behavior) wajib pajak dalam kemauan membayar perpajakannya. Semakin tinggi pemahaman akan peraturan perpajakan wajib pajak maka wajib pajak akan mengaplikasikan pengetahuan itu untuk membayar pajak. Begitupun sebaliknya semakin rendah kesadaran wajib pajak dalam melaporkan kewajiban perpajakannya disebabkan oleh pemahaman tentang pajak masih rendah. Berdasarkan hal tersebut hipotesis dapat dirumuskan sebagai berikut:

H1: Pengetahuan dan pemahaman tentang peraturan perpajakan berpengaruh terhadap kemauan membayar pajak.

\section{B.8.2 Pengaruh Pengetahuan dan Pemahaman tentang Peraturan Perpajakan terhadap Kemauan Membayar Pajak melalui Kesadaran Membayar Pajak}

Pengetahuan akan peraturan perpajakan merupakan sikap atau tingkah laku seseorang dalam memahami pajak dan peraturanperaturan perpajakan yang didapat melalui upaya pengajaran formal maupun nonformal sehingga berdampak positif terhadap kemauan wajib pajak untuk membayar pajak. Seperti pengetahuan peraturan perpajakan dalam sistem perpajakan yang baru, wajib pajak diberikan kepercayaan melalui sistem untuk menghitung, memperhitungkan, membayar dan melaporkan sendiri pajak yang terutang sehingga dengan adanya sistem ini diharapkan para wajib pajak tahu akan fungsi pembayaran pajak dan fungsi pajak untuk mengatur atau melaksanakan kebijakan pemerintah dalam bidang sosial atau ekonomi. Menurut Nugroho (2012), faktor-faktor yang mempengaruhi kemauan membayar pajak dengan kesadaran membayar pajak sebagai variabel intervening, hasil tersebut sama dengan penelitian Indrawan (2014) yang menunjukkan hubungan signifikan terhadap kesadaran membayar pajak. Berdasarkan hal tersebut hipotesis dapat dirumuskan sebagai berikut:

H2: Pengetahuan dan pemahaman tentang peraturan perpajakan berpengaruh terhadap kemauan membayar pajak melalui kesadaran membayar pajak.

\section{B.8.3 Pengaruh Kualitas Pelayanan terhadap Kemauan Membayar Pajak}

Pelayanan fiskus dapat diartikan sebagai cara petugas pajak dalam membantu mengurus atau menyiapkan segala keperluan yang dibutuhkan wajib pajak (Jatmiko, 2006). Di dalam Theory of Planned Behavior (TPB) kualitas pelayanan yang diberikan oleh fiskus berkaitan dengan 
kepercayaan normatif (normative beliefs). Dengan adanya pelayanan yang baik dari petugas pajak dapat mempengaruhi seseorang wajib pajak untuk berperilaku dalam memenuhi perpajakannya. Begitupun sebaliknya, jika pelayanan yang diberikan petugas pajak tidak baik maka wajib pajak enggan untuk membayar pajak. Menurut Hardiningsih (2011), kualitas pelayanan berpengaruh positif terhadap kemauan membayar pajak. Apabila kualitas pelayanan yang baik kepada wajib pajak akan dapat meningkatkan kemauan wajib pajak dalam memenuhi kewajiban perpajakan, dengan adanya hal tersebut dapat dirumuskan hipotesis:
H3: Kualitas pelayanan berpengaruh terhadap kemauan membayar pajak.

\section{B.8.4 Pengaruh Kualitas Pelayanan terhadap Kemauan Membayar Pajak melalui Kesadaran Membayar Pajak}

Pelayanan perpajakan diukur melalui ketentuan perpajakan, kualitas SDM dan sistem informasi perpajakan. Dalam penelitian Efendi (2014), pelayanan yang baik merupakan salah satu faktor penting dalam menciptakan kepuasan kepada pelanggan. Suatu layanan dapat dikatakan baik apabila usaha yang dijalankan sesuai dengan apa yang diharapkan. Pelayanan yang berkualitas adalah pelayanan yang dapat memberikan kepuasan kepada pelanggan dan tetap dalam batas memenuhi standar pelayanan yang dapat dipertanggungjawabkan serta harus dilakukan secara terus-menerus. Nugroho (2012) dan Syahri (2014) menyimpulkan bahwa pelayanan yang berkualitas berpengaruh postif terhadap kesadaran membayar pajak, kemudian variabel kesadaran membayar pajak berpengaruh positif terhadap kemauan membayar pajak. Berdasarkan hal tersebut dapat dirumuskan hipotesis yaitu:

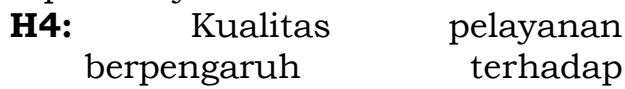

kemauan membayar pajak melalui kesadaran membayar pajak.

B.8.5 Pengaruh Persepsi atas Efektivitas Sistem Perpajakan terhadap Kemauan Membayar Pajak

Selama ini banyak wajib pajak yang telah terdaftar sebagai wajib pajak dan telah memiliki NPWP belum mau melaksanakan kewajiban pajak dengan baik. Hal ini disebabkan oleh asas perpajakan bahwa hasil pemungutan pajak tidak langsung dinikmati oleh pembayar pajak. Persepsi atas efektivitas sistem perpajakan dalam Theory of Planned Behavior (TPB) berkaitan dengan persepsi wajib pajak dalam menentukan perilakunya (percived control behavior) dalam kemauan membayar pajak. Apabila wajib pajak merasa bahwa sistem perpajakan yang ada adalah terpercaya, handal dan akurat, maka wajib pajak mau membayar pajak. Namun apabila sebaliknya maka hal tersebut dapat mempengaruhi kemauan wajib pajak dalam melaksanakan perpajakannya. Menurut Fikriningrum (2012), persepsi efektivitas sistem perpajakan berpengaruh positif terhadap kemauan membayar pajak. Hal yang sama dengan penelitian Pratomo (2014) mengenai pengaruh kesadaran, pengetahuan, persepsi dan tingkat kepercayaan terhadap kemauan membayar pajak. Sedangkan penelitian yang dilakukan Nurlis (2010) menemukan pengaruh persepsi tidak signifikan terhadap kemauan membayar pajak. Berdasarkan uraian di atas dapat dirumuskan suatu hipotesis sebagai berikut:

H5: Persepsi atas efektivitas
sistem
berpengaruh
kemauan membayar pajak.




\begin{tabular}{llr}
\hline B.8.6 Pengaruh & Persepsi atas \\
Efektivitas Sistem & Perpajakan \\
terhadap Kemauan & Membayar \\
Pajak $\quad$ melalui & Kesadaran \\
Membayar Pajak &
\end{tabular}

Persepsi wajib pajak terhadap sistem perpajakan di Indonesia berkaitan dengan media yang digunakan dalam membayar pajak. Jika wajib pajak merasa bahwa sistem perpajakan yang ada adalah terpercaya, handal dan akurat, maka wajib pajak akan memiliki pandangan yang positif untuk sadar membayar pajak. Namun jika sistem perpajakan yang ada tidak memuaskan bagi wajib pajak, maka hal itu dapat turut mempengaruhi kesadaran wajib pajak. Menurut Syahri (2014), efektivitas sistem perpajakan berpengaruh signifikan terhadap kesadaran membayar pajak. Hasil yang sama diperoleh oleh Indrawan (2014). Semakin efektif sistem perpajakan yang ada maka pencitraan tentang efektivitas sistem perpajakan akan baik sehingga dapat meningkatkan kemauan wajib pajak untuk membayar pajak. Berdasarkan uraian di atas dapat dirumuskan suatu hipotesis sebagai berikut:

H6: Persepsi atas efektivitas sistem perpajakan berpengaruh terhadap kemauan membayar pajak melalui kesadaran membayar pajak.

\section{METODE PENELITIAN}

Populasi dalam penelitian ini adalah Wajib Pajak Orang Pribadi yang melakukan pekerjaan bebas yang terdaftar di KPP Pratama Ternate. Pekerjaan bebas yang dimaksud meliputi pengacara, dokter maupun bidan yang membuka praktek kerja sendiri, apoteker, notaris, konsultan dan lain-lain. Tehnik pengambilan sampel yang digunakan dalam penelitian ini adalah random sampling, yaitu cara pengambilan sampel yang memberikan kesempatan yang sama untuk diambil kepada setiap elemen populasi (Kuncoro, 2013). Teknik pengumpulan data dalam penelitian ini adalah teknik angket (kuesioner), membaca dan mempelajari literatur yang berkaitan dengan topik yang dipilih dan menggunakan metode survei langsung dengan menggunakan kuesioner. Metode analisis yang digunakan adalah metode analisis jalur (path analysis) yang mana bertujuan untuk menguji pengaruh variabel intervening yang merupakan perluasan dari analisis regresi linier berganda (Ghozali, 2013).

\section{HASIL PENELITIAN}

\section{D.1 Profil Responden}

Sampel penelitian ini meliputi 86 responden yang merupakan Wajib Pajak Orang Pribadi yang melakukan pekerjaan bebas yang terdaftar di KPP Pratama Ternate. Profil dari 86 responden yang ikut berpartisipasi dalam penelitian ini ditunjukkan dalam Tabel 2. Dari hasil pengolahan data akan dijelaskan mengenai jenis kelamin, usia dan profesi. Hasil penelitian berdasarkan deskriptif identitas responden dalam penelitian ini adalah sebagai berikut:

Tabel 2

Profil Responden

\begin{tabular}{|r|c|c|c|}
\hline No & Keterangan & Jumlah & Persentase (\%) \\
\hline $\mathbf{1}$ & Jenis Kelamin & & \\
\hline & Laki-Laki & 33 & $38.37 \%$ \\
\hline & Perempuan & 53 & $61.63 \%$ \\
\hline $\mathbf{2}$ & Usia & & \\
\hline & $25-35$ Tahun & 20 & $23.26 \%$ \\
\hline & 36-46 Tahun & 56 & $65.12 \%$ \\
\hline & diatas 47 Tahun & 10 & $11.63 \%$ \\
\hline $\mathbf{3}$ & Profesi & & \\
\hline & Advokad & 1 & $1.16 \%$ \\
\hline
\end{tabular}




\begin{tabular}{|l|l|c|c|}
\hline No & Keterangan & Jumlah & Persentase (\%) \\
\hline & Apoteker & 21 & $24.42 \%$ \\
\hline & Bidan & 1 & $1.16 \%$ \\
\hline & Dokter & 55 & $63.95 \%$ \\
\hline & Notaris & 8 & $9.30 \%$ \\
\hline
\end{tabular}

Sumber: Diolah penulis, 2018

Berdasarkan data statistik frekuensi di atas terlihat bahwa responden wanita dalam penelitian ini lebih banyak daripada responden laki-laki. Responden wanita berjumlah sebanyak 53 orang atau $61,62 \%$ dari total responden. Sedangkan responden yang berjenis kelamin laki- laki sebanyak 33 orang atau 38,37\% dari keseluruhan responden atau berbeda 23,25\% dari responden wanita. Berdasarkan usia, Tabel 2 menunjukkan bahwa responden didominasi pada usia antara 36 tahun sampai 46 tahun yaitu sebanyak 56orang atau $61,11 \%$, usia 25 tahun sampai dengan 35 tahun berjumlah 20 orang atau 23,25\% dan usia 57 tahun ke atas berjumlah 10 orang atau 11,62\%. Dari Tabel 2 diketahui bahwa mayoritas jumlah sampel pekerjaan bebas yang berprofesi dokter sebanyak $63,95 \%$, advokad sebanyak 1,16\%, apoteker sebanyak 24,41\%, bidan sebanyak $1,16 \%$ dan notaries sebanyak 9,30\%.

\section{D.2 Statistik Deskriptif}

Berikut ini adalah hasil pengujian statistik deskriptif dari variabel- variabel yang digunakan dalam penelitian ini yaitu pengetahuan dan pemahaman tentang peraturan perpajakan, kualitas pelayanan dan persepsi yang baik atas efektivitas sistem perpajakan sebagai variabel bebas (independen), kemauan membayar pajak sebagai variabel terikat (dependen) dan kesadaran membayar pajak sebagai variabel intervening.

Tabel 3

Statistik Deskriptif

\begin{tabular}{|c|c|c|c|c|c|c|c|}
\hline \multirow{2}{*}{ Variabel } & \multicolumn{3}{|c|}{ Kisaran Teoritis } & \multicolumn{3}{|c|}{ Kisaran Aktual } & \multirow{2}{*}{$\begin{array}{l}\text { Standar } \\
\text { Deviasi }\end{array}$} \\
\hline & Min & Max & Mean & Min & Max & Mean & \\
\hline $\begin{array}{l}\text { Pemahaman Aturan } \\
\text { Perpajakan }\end{array}$ & 7 & 35 & 21 & 17 & 33 & 26.00 & 3.528 \\
\hline Kualitas Pelayanan & 4 & 20 & 12 & 9 & 20 & 16.07 & 2.146 \\
\hline $\begin{array}{l}\text { Persepsi atas Efektifikan } \\
\text { Sistem Perpajakan }\end{array}$ & 5 & 25 & 15 & 12 & 25 & 19.76 & 3.378 \\
\hline Kesadaran Membayar Pajak & 6 & 30 & 18 & 18 & 29 & 25.19 & 2.339 \\
\hline Kemauan Membayar Pajak & 5 & 25 & 15 & 14 & 25 & 20.67 & 2.383 \\
\hline
\end{tabular}

Sumber: Diolah penulis, 2018

\section{D.3 Uji Kualitas Data \\ D.3.1 Uji Validitas}

Pengujian validitas dalam penelitian ini menggunakan faktor konfirmatori yang bertujuan untuk menguji apakah suatu variabel mempunyai uji dimensionalitas atau apakah indikator-indikator yang digunakan dapat mengkonfirmasikan sebuah variabel. Jika masing-masing indikator merupakan indikator pengukur maka akan memiliki nilai loading factor yang tinggi. Asumsi yang mendasari dapat tidaknya digunakan analisis faktor adalah data matriks harus memiliki korelasi yang cukup (sufficient correlation). Uji Bartlett of sphericity merupakan uji statistik untuk ada tidaknya korelasi antara variabel, semakin besar sampel menyebabkan bartkett test semakin sensitif untuk mendeteksi adanya korelasi antar variabel. Alat uji lain yang digunakan untuk mengukur tingkat interkorelasi antar variabel dan dapat tidaknya dilakukan analisis faktor adalah Kaiser-MeyerOlkin Measure of Sampling Adequacy (KMOMSA). Nilai KMO bervariasi dari 0 sampai dengan 1 . 
Nilai yang dikehendaki harus > 0,50 untuk dapat dilakukan analisis faktor (Ghozali, 2013). Berdasarkan hasil uji validitas instrumen terlihat bahwa seluruh instrument di atas adalah valid, karena nilai Kaiser-Meyer-Olkin Measure of Sampling Adequacy (KMOMSA) masing-masing instrumen tersebut lebih besar dari $r$ tabel $(0,50)$. Hal ini berate bahwa instrumen yang digunakan untuk mengukur variabel pengetahuan dan pemahaman peraturan perpajakan, kualitas pelayanan, persepsi atas efektivitas sistem perpajakan, kesadaran membayar pajak dan kemauan membayar pajak dapat digunakan untuk mengukur setiap variabel dalam penelitian ini.

\section{D.3.2 Uji Reliabilitas}

Pada pengujian ini dilakukan guna menguji konsistensi jawaban responden atas seluruh butir pertanyaan atau pernyataan yang digunakan. Pengujian reabilitas bertujuan untuk mengetahui apakah instrument yang dalam hal ini kuesioner dapat digunakan lebih dari satu kali, paling tidak oleh responden yang sama. Uji reliabilitas merupakan alat untuk mengukur suatu kuesioner yang merupakan indikator dari variabel. Suatu kuesioner dikatakan reliabel jika jawaban seseorang terhadap pertanyaan adalah bebas dari bias dan konsisten atau stabil dari waktu ke waktu (Ghozali, 2013). Pengujian ini dilakukan dengan menghitung koefisien Cronbach Alpha (a) dari masing-masing instrumen dalam satu variabel. Suatu variabel disebut reliable apabila hasil a $\geq 0,60$ (Ghozali, 2013). Berdasarkan hasil uji reliabilitas variabel terlihat bahwa seluruh variabel di atas adalah reliabel, karena nilai Cronbach Alpha masing-masing instrument tersebut lebih besar dari 0,60. Hal ini berarti bahwa instrument yang digunakan untuk mengukur variabel pengetahuan dan pemahaman peraturan perpajakan, kualitas pelayanan, persepsi atas efektivitas sistem perpajakan, tingkat kepercayaan terhadap sistem pemerintahan dan hukum, kesadaran membayar pajak dan kemauan membayar pajak dapat digunakan untuk mengukur setiap variabel dalam penelitian ini.

\section{D.4 Intepretasi Model}

Penelitian ini bertujuan untuk mengetahui pengaruh pengetahuan dan pemahaman tentang peraturan perpajakan, kualitas pelayanan dan persepsi atas efektivitas sistem perpajakan terhadap kemauan membayar pajak dan kesadaran membayar pajak sebagai variabel intervening. Pengujian ini terdapat persamaan substruktur I dan persamaan substruktur II. Dalam persamaan substruktur I yang diuji dalam pengujian ini apakah pengetahuan dan pemahaman tentang peraturan perpajakan, kualitas pelayanan dan persepsi yang baik atas efektivitas sistem perpajakan secara bersama-sama (simultan) dan parsial mampu mempengaruhi kesadaran membayar pajak atau tidak.

Untuk persamaan substruktur II yang diuji dalam penelitian ini adalah pengaruh variabel pengetahuan dan pemahaman tentang peraturan perpajakan, kualitas pelayanan, persepsi yang baik atas efektivitas sistem perpajakan dan kesadaran membayar pajak sebagai variabel intervening secara bersama-sama (simultan) atau secara parsial mempu mempengaruhi variabel kemauan membayar pajak atau tidak. Sehingga dapat diketahui pengaruh langsung dan pengaruh tidak langsung pengetahuan dan pemahaman tentang peraturan perpajakan, kualitas pelayanan dan persepsi yang baik atas efektivitas sistem perpajakan terhadap kemauan membayar pajak dan kesadaran membayar pajak sebagai variabel intervening.

\section{D.5 Analisis Jalur}

D.5.1 Persamaan Substruktur I

Persamaan substruktur I menguji pengaruh pengetahuan dan pemahaman tentang peraturan 
perpajakan, kualitas pelayanan, persepsi yang baik atas efektivitas sistem perpajakan, tingkat kepercayaan pemerintahan dan hukum terhadap variabel kesadaran membayar pajak sebagai variabel intervening. Pengujian substruktur I dilakukan dengan menggunakan regresi linear berganda dengan analisis jalur yang hasilnya sebagai berikut:

Tabel 4

Hasil Path Analysis Persamaan Substruktur I

\begin{tabular}{lcccc}
\hline \multicolumn{1}{c}{ Variabel Penelitian } & Standarized Coefficients & $\begin{array}{c}\text { T } \\
\text { Hitung }\end{array}$ & Sig \\
\hline \multicolumn{1}{c}{ Constant } & & & 5.802 & 0.000 \\
\hline Pemahaman Aturan Perpajakan & & 0.294 & 3.185 & 0.002 \\
\hline Kualitas Pelayanan & & 0.305 & 3.019 & 0.003 \\
\hline Persepsi Atas Efektifitas Sistem & & -0.364 & -2.678 & 0.009 \\
Perpajakan & & & & \\
\hline R & 0.567 & & & \\
R Square & 0.322 & & & \\
Adjust R Square & 0.288 & & & \\
F. Hitung & 9.612 & & & \\
Sig F & 0.000 & & & \\
N & 86 & & & \\
\hline Sumber: Output SPSS 2018 & & & & \\
\hline
\end{tabular}

Sumber: Output SPSS, 2018

Dari hasil pemrosesan data di atas dapat dilihat bahwa nilai uji $\mathrm{F}$ adalah 9.612 dengan nilai signifikan yaitu $0.000<0.05$. Hal ini menunjukan bahwa variabel pengetahuan dan pemahaman tentang peraturan perpajakan, kualitas pelayanan, persepsi yang baik atas efektivitas sistem perpajakan secara bersama-sama mampu menjelaskan variabel kesadaran membayar pajak. Untuk menentukan adanya pengaruh variabel kesadaran membayar pajak, maka dapat ditentukan dengan cara:

$$
e 1=\sqrt{1-R^{2}}=\sqrt{1-0,322}=0,823
$$

Maka nilai e1 koefisien jalur variabel lain terhadap kesadaran membayar pajak pada wajib pajak orang pribadi yang melakukan pekerjaan bebas sebesar $82.3 \%$ sehingga persamaan jalurnya adalah:

$\mathrm{KSMP}=0,294+0,305-0,364+$ $0,453+0,823$

Hasil output SPSS memberikan nilai koefisien standardized beta pengetahuan dan pemahaman tentang peraturan perpajakan pada persamaan substruktur I sebesar 0.294 dan signifikan pada $0.002<$ 0.05 yang berarti pengetahuan dan pemahaman tentang peraturan perpajakan mempengaruhi kesadaran membayar pajak. Nilai koefisien standardized beta 0.294 merupakan nilai path. Standardized beta kualitas pelayanan pada persamaan substruktur I sebesar 0,305 dan signifikan pada $0,003<0,05$ yang berarti kualitas pelayanan mempengaruhi kesadaran membayar pajak. Nilai koefisien standardized beta 0,305 merupakan nilai path. Standardized beta persepsi yang baik atas efektivitas sistem perpajakan pada persamaan substruktur I -0,364 dan signifikan pada $0,009<0,05$ yang berarti persepsi yang baik atas efektivitas sistem perpajakan mempengaruhi kesadaran membayar pajak. Nilai koefisien standardized beta $-0,364$ merupakan nilai path.

\section{D.5.2 Persamaan Substruktur II}

Persamaan substruktur II menguji pengaruh langsung dan pengaruh tidak langsung pengaruh pengetahuan dan pemahaman tentang peraturan perpajakan, kualitas pelayanan, persepsi yang baik atas efektivitas sistem perpajakan terhadap kemauan membayar pajak dan kesadaran membayar pajak sebagai variabel intervening. Pengujian substruktur II dilakukan dengan menggunakan 
Tabel 5

Hasil Path Analysis Persamaan Substruktur II

\begin{tabular}{|c|c|c|c|}
\hline Variabel Penelitian & $\begin{array}{l}\text { Standarized } \\
\text { Coefficients }\end{array}$ & $\begin{array}{c}\text { T } \\
\text { Hitung }\end{array}$ & Sig \\
\hline Constant & & 3.510 & 0.001 \\
\hline $\begin{array}{l}\text { Pemahaman Aturan } \\
\text { Perpajakan }\end{array}$ & -0.120 & -2.152 & 0.034 \\
\hline Kualitas Pelayanan & 0.138 & 2.271 & 0.026 \\
\hline $\begin{array}{l}\text { Persepsi Atas Efektifitas } \\
\text { Sistem Perpajakan }\end{array}$ & 0.717 & 8.847 & 0.000 \\
\hline Kesadaran Membayar Pajak & 0.128 & 2.009 & 0.048 \\
\hline $\mathrm{R}$ & 0.884 & & \\
\hline R Square & 0.781 & & \\
\hline Adjust R Square & 0.766 & & \\
\hline F. Hitung & 57.128 & & \\
\hline $\operatorname{Sig} \mathrm{F}$ & 0.000 & & \\
\hline $\mathrm{N}$ & 86 & & \\
\hline
\end{tabular}

Sumber: Output SPSS, 2018

Berdasarkan tabel di atas, nilai $R$ square menunjukan 0,781 . Hal ini menunjukan bahwa kontribusi variabel pengetahuan dan pemahaman tentang peraturan perpajakan, kualitas pelayanan dan persepsi yang baik atas efektivitas sistem perpajakan secara bersamasama mampu menjelaskan pengaruhnya terhadap kemauan membayar pajak melalui kesadaran membayar pajak yaitu $78,1 \%$, sedangkan 21,9\% ditentukan oleh variabel lain yang tidak diteliti dalam penelitian ini. Untuk menentukan adanya pengaruh variabel lain terhadap kemauan membayar pajak melalui kesadaran membayar pajak, maka dapa tditentukan dengan cara:

$$
e 2=\sqrt{1-R^{2}}=\sqrt{1-0.781}=0.467
$$

Maka nilai koefisien jalur variabel lain terhadap kemauan membayar pajak pada wajib pajak orang pribadi yang melakukan pekerjaan bebas sebesar 46,7\%. sehingga persamaan jalurnya adalah:

$\mathrm{KMP}=-0,120+0,138+0,717+$ $0,128+0,467$

Pada output SPSS persamaan regresi (2) nilai standardized beta untuk pengetahuan dan pemahaman tentang peraturan perpajakan -0,120 dan kesadaran membayar pajak 0,128 dengan tingkat signifikan masing-masing
0,034 dan 0,048 yang mana tingkat signifikan keduanya < 0,05 dapat disimpulkan keduanya signifikan. Nilai standardized beta $-0,120$ merupakan nilai jalur path dan nilai standardized beta kesadaran membayar pajak 0,128 merupakan nilai jalur path. Nilai standardized beta untuk kualitas pelayanan 0,138 dan kesadaran membayar pajak 0,128 keduanya memiliki tingkat signifikan 0,026 dan 0,048 dapat simpulkan keduanya signifikan karena tingkat signifikannya $<0,05$. Nilai standardized beta 0,138 merupakan nilai jalur path dan nilai standardized beta kesadaran membayar pajak 0,128 merupakan nilai jalur. Nilai standardized beta untuk persepsi yang baik efektivitas sistem perpajakan 0,717 dan kesadaran membayar pajak 0,128 masing-masing memiliki tingkat signifikan 0,000 dan 0,048 dapat disimpulkan keduanya signifikan karena tingkat signifikannya $<0,05$. Nilai standardized beta 0,717 merupakan nilai jalur path dan nilai standardized beta kesadaran membayar pajak 0,128 merupakan nilai jalur path.

\section{D.5.3 Uji F}

Dari hasil pemrosesan data, dapat dilihat bahwa uji $\mathrm{F} 57,128$ dengan nilai signifikansi $0,000<$ 
0,05 hal ini menunjukan bahwa variabel pengetahuan dan pemahaman tentang peraturan perpajakan, kualitas pelayanan, persepsi yang baik atas efektivitas sistem perpajakan, tingkat kepercayaan pemerintahan dan hukum secara bersama-sama mampu menjelaskan pengaruhnya terhadap kemauan membayar pajak melalui kesadaran membayar pajak.

\section{D.6 Pembahasan}

D.6.1 Pengetahuan dan Pemahaman tentang Peraturan Perpajakan Berpengaruh terhadap Kemauan Membayar Pajak

Hasil penelitian ini menunjukkan variabel pengetahuan dan pemahaman tentang peraturan perpajakan berpengaruh negatif terhadap kemauan membayar pajak. Hal ini dapat dijelaskan dengan rekapitulasi jawaban responden, hal yang perlu menjadi perhatian dalam hal pengetahuan dan pemahaman peraturan perpajakan berkaitan dengan kewajiban mendaftarkan NPWP, serta pengetahuan dan pemahaman peraturan perpajakan diperoleh dari training, hasil penelitian menunjukkan bahwa responden tidak setuju dengan hal tersebut. Hal ini disebabkan karena para pekerja profesional mempunyai kemauan yang rendah dalam hal pelaporan kewajiban perpajakannya, serta kurang tegasnya sanksi yang diberikan oleh petugas pajak, sehingga mereka kurang menyadari betapa pentingnya pembayaran pajak dan menganggap sanksi yang akan diberikan oleh petugas pajak kepada wajib pajak hanya mainmain dan tidak akan pernah dilaksanakan, karena di negara Indonesia masih banyak pekerja profesional yang menghindari pajak serta menunggak pajak. Menurut Prasetyo (2006) masyarakat enggan membayar pajak salah satunya disebabkan karena perkembangan intelektual dan moral dari masyarakat. Selain itu, berdasarkan pengamatan di lapangan wajib pajak meragukan kredibilitas peraturan perpajakan akibat adanya berbagai kasus pajak yang terjadi saat ini, terutama akibat munculnya kasus Gayus Tambunan dan kasuskasus perpajakan lainnya.

Hasil penelitian ini konsisten dengan penelitian yang dilakukan oleh Fitryani (2014). Selain itu, diperkuat dengan penelitian yang dilakukan oleh Hardianingsih (2011) dan Ramadhani (2014) yang menyatakan pengetahuan dan pemahaman tentang peraturan pajak tidak berpengaruh terhadap kemauan membayar pajak. Hasil penelitian ini juga mendukung Theory of Planned Behavior (TPB) pada control beliefs yaitu keyakinan tentang keberadaan hal-hal yang mendukung atau menghambat perilaku yang akan ditampilkan (control beliefs) dan persepsinya tentang seberapa kuat (perceived power) tingkah laku yang dipersepsikannya yaitu kemampuan mereka untuk melakukan tindakan tersebut. Hal ini dikarenakan TPB seharusnya merupakan penentu penting mengenai apakah sistem dipercaya dapat lebih bermanfaat, lebih penting atau relatif dapat memberikan keuntungan yang lebih. Oleh sebab itu, Theory of Planned Behavior (TPB) sangat mendukung.

D.6.2 Pengetahuan r dan
Pemahaman tentang Peraturan
Perpajakan Berpengaruh terhadap
Kemauan Membayar Pajak
melalui Kesadaran Membayar
Pajak

Pengetahuan dan pemahaman tentang peraturan perpajakan berpengaruh secara tidak langsung terhadap kemauan membayar pajak melalui kesadaran membayar pajak. Hasil ini menjelaskan bahwa kesadaran membayar pajak meningkatkan pengaruh pengetahuan dan pemahaman tentang peraturan perpajakan terhadap kemauan membayar pajak WPOP yang melakukan pekerjaan bebas. Hasil tersebut 
konsisten dengan penelitian yang dilakukan oleh Nugroho (2012) dan Indrawan (2014) yang menyatakan bahwa ada perbedaan pengetahuan tentang pajak antara wajib pajak yang patuh dan tidak patuh. Salah satu penyebab berpengaruhnya pengetahuan pajak terhadap kesadaran wajib pajak, sebagian besar wajib pajak memeperoleh pengetahuan pajak dari radio, televisi, internet, surat kabar, buku perpajakan, seminar dan pelatihan perpajakan. Bertambahnya wawasan wajib pajak mampu memeberikan kesadaran akan pentingnya pajak bagi mereka. Tatiana (2009) dalam penelitianya menyatakan beberapa bentuk kesadaraan membayar pajak yang mendorong wajib pajak bersedia untuk membayar pajak. Terdapat tiga bentuk utama yang terkait dengan pembayaran pajak. Pertama, kesadaran bahwa pajak merupakan bentuk partisipasi dalam menunjang pembangunan negara. Dengan menyadari hal ini, wajib pajak mau membayar pajak karena merasa tidak dirugikan dari pemungutan pajak yang dilakukan. Pajak disadari digunakan untuk pembangunan negara guna meningkatkan kesejahteraan warga negara. Kedua, kesadaran bahwa penundaan pembayaran pajak dan pengurangan beban pajak sangat merugikan negara. Ketiga, kesadaran bahwa pajak ditetapkan dengan undang-undang dan dapat dipaksakan. Hal ini menunjukan bahwa jika kesadaran membayar pajak semakin tinggi, maka semakin besar kemauan wajib pajak.

Hasil ini juga sejalan dengan Theory of Planned Behavior (TPB) menyatakan bahwa selain sikap terhadap tingkah laku dan normanorma subjektif, individu juga mempertimbangkan kontrol tingkah laku yang dipersepsikannya yaitu kemampuan mereka untuk melakukan tindakan tersebut. Sehingga dapat dikatakan bahwa kesadaran membayar pajak memiliki peran yang mempengaruhi pengetahuan dan pemahaman tentang peraturan perpajakan terhadap kemauan membayar pajak.

\section{D.6.3 Kualitas Pelayanan Berpengaruh terhadap Kemauan Membayar Pajak}

Hasil penelitian variabel kualitas pelayanan berpengaruh secara langsung terhadap kemauan membayar pajak. Hal ini menunjukan semakin baik kualitas pelayanan yang diberikan maka semakin meningkat kemauan untuk membayar pajak wajib pajak orang pribadi yang melakukan pekerjaan bebas. Secara umum kualitas pelayanan yang diberikan petugas pajak semakin baik yang ditunjukkan dalam hal pengadaan fasilitas yang menunjang kenyamanan para Wajib Pajak, misalnya penggunaan sistem informasi dan teknologi untuk memberikan kemudahan kepada Wajib Pajak dalam memenuhi kewajiban pajaknya, penampilan gedung yang lebih modern dan terkesan rapi serta pelayanan yang lebih cepat dari petugas pajak dapat meningkatkan kepuasan pelanggan atau dalam hal ini Wajib Pajak sehingga berdampak terhadap kemauan membayar pajak oleh wajib pajak semakin meningkat. Hal ini menunjukkan sikap wajib pajak cukup memiliki kepercayaan terhadap pelayanan yang berkualitas yang telah dilakukan oleh fiskus, bahwa wajib pajak telah mendapatkan pelayanan yang cukup baik dari aparat pajak dengan selalu memperhatikan keinginan wajib pajak. Maka pelayanan berkualitas tetap dijaga dan diperhatikan oleh Kantor Pajak maupun Ditjen Pajak. Pelayanan yang berkualitas harus diupayakan dapat memberikan 4K yaitu keamanan, kelancaran, kenyamanan dan kepastian hukum yang dapat dipertanggungjawabkan. Sehingga diharapkan pemerintah dapat mengurangi kebocoran-kebocoran pajak yang dilakukan oleh petugas kantor pelayanan pajak atau dari pemerintah. Penelitian ini 
konsisten dengan penelitian yang dilakukan oleh Hardiningsih (2011), Setiyawati (2013) dan Fitriyani (2014).

Hasil penelitian ini juga mendukung Theory of Planned Behavior tentang kepercayaankepercayaan normative (normative beliefs), yaitu keyakinan tentang harapan normatif orang lain dan motivasi untuk memenuhi harapan tersebut (normative beliefs and motivation to comply), dengan adanya pelayanan yang baik dari petugas pajak, sistem perpajakan yang efisien dan efektif, serta penyuluhan-penyuluhan pajak yang memberikan motivasi kepada wajib pajak agar taat pajak, akan membuat wajib pajak memiliki keyakinan atau memilih perilaku taat pajak.

\section{D.6.4 Kualitas Pelayanan Berpengaruh terhadap Kemauan Membayar Pajak melalui Kesadaran Membayar Pajak}

Kualitas pelayanan dapat berpegaruh secara tidak langsung terhadap kemauan membayar pajak melalui variabel intervening. Hal tersebut konsisten dengan penelitian yang dilakukan oleh Nugroho (2012) dan Syahri (2014), bahwa pelayanan yang berkualitas adalah pelayanan yang dapat memberikan kepuasan kepada pelanggan dan tetap dalam batas memenuhi standar pelayanan yang dapat dipertanggungjawabkan serta harus dilakukan secara terusmenerus. Dengan peningkatan kualitas pelayanan diharapkan akan menumbuhkan rasa kesadaran kepada masyarakat untuk mau membayar pajak yang kemudian akan membawa dampak yang positif pada pendapatan negara. Meningkatnya penerimaan pajak dapat memberikan arti yang positif bagi pembangunan negara. Peningkatan penerimaan pajak negara dapat dijadikan elemen penting penilaian bahwa kinerja organisasi dengan segenap pelayanan yang berkualitas dan kinerja pegawainya sudah menunjukkan hasil yang baik. Pelayanan yang berkualitas terhadap wajib pajak adalah usaha yang dilakukan oleh kantor pelayanan pajak untuk melayani wajib pajak secara maksimal agar wajib pajak tidak mengalami kebingungan saat membayar pajak.

Hasil penelitian ini juga didukung oleh Theory of Planned Behavior tentang kepercayaankepercayaan normatif (normative beliefs), dengan pelayanan yang baik dari petugas pajak akan mempengaruhi dan memotivasi seorang wajib pajak untuk berperilaku untuk memenuhi kewajiban perpajakannya.

\section{D.6.5 Persepsi yang Baik atas Efektivitas Sistem Perpajakan Berpegaruh terhadap Kemauan Membayar Pajak}

Hasil penelitian ini menunjukkan variabel persepsi atas efektivitas sistem perpajakan berpengaruh secara langsung terhadap kemauan membayar pajak. Hasil tersebut dijelaskan bahwa WPOP yang melakukan pekerjaan bebas memiliki persepsi yang baik atas efektivitas sistem perpajakan. Dirjen Pajak selalu memperbaharui sistem yang ada dengan tujuan agar memberi kemudahan bagi wajib pajak dalam menjalankan kewajiban perpajakannya. Dalam hal ini wajib pajak sudah memaksimalkan sistem perpajakan baru yang berbasis online seperti meng-update peraturan perpajakan melalui jaringan internet ataupun menggunakan fasilitas yang dikeluarkan Dirjen Pajak yang berbasis internet pula, sehingga wajib pajak lebih dimudahkan dalam pembayaran pajaknya. Hal ini konsisten dengan hasil penelitian Fikriningrum (2012) dan Pratomo (2014) yang menyebutkan bahwa persepsi yang baik akan memberikan pengaruh positif terhadap suatu peristiwa yang diamatinya. Semakin baik persepsi atas efektivitas sistem perpajakan maka semakin tinggi kemauan wajib pajak dalam membayar pajak.

Hasil penelitian ini juga mendukung Theory of Planned 
Behavior berkaitan dengan control beliefs menyatakan keyakinan tentang keberadaan hal-hal yang mendukung atau menghambat perilaku yang akan ditampilkan, dan persepsinya tentang seberapa kuat hal-hal yang mendukung dan menghambat perilakunya tersebut (perceived power) tingkah laku yang dipersepsikannya yaitu kemampuan mereka untuk melakukan tindakan tersebut.

D.6.6 Persepsi yang Baik atas Efektivitas Sistem Perpajakan Berpegaruh terhadap Kemauan Membayar Pajak melalui Kesdaran Membayar Pajak

Persepsi atas efektivitas sistem perpajakan dapat berpengaruh secara tidak langsung terhadap kemauan membayar pajak melalui variabel intervening. Sehingga variabel kesadaran mampu memediasi hubungan antara persepsi yang baik atas efektivitas sistem perpajakan terhadap kemauan membayar pajak. Hal tersebut konsisten dengan hasil penelitian yang dilakukan oleh Syahri (2014) dan Indrawan (2014) variabel persepsi yang baik atas efektivitas sistem perpajakan menyatakan berpengaruh terhadap kesadaran membayar pajak. Dalam kaitanya dengan kesadaran membayar pajak, maka adanya persepsi yang baik dari wajib pajak sangat penting. Dalam prakteknya, efektivitas sistem perpajakan tidak memberikan pelayanan terbaik kepada masyarakat untuk mempermudah wajib pajak dalam melaksanakan kewajiban perpajakannya, dan hal tersebut menimbulkan keengganan wajib pajak untuk mau membayar pajak. Kondisi seperti ini akan berpengaruh pada kemauan wajib pajak yang rendah dalam membayar pajak. Dengan menerapkan sistem perpajakan yang lebih memudahkan wajib pajak, diharapkan akan dapat mendorong kemauan wajib pajak dalam membayar iuran pajaknya kepada Negara. Hasil ini juga sejalan dengan Theory of Planned Behavior (TPB) menyatakan bahwa selain sikap terhadap tingkah laku dan norma-norma subjektif, individu juga mempertimbangkan kontrol tingkah laku yang dipersepsikannya yaitu kemampuan mereka untuk melakukan tindakan tersebut.

\section{E. PENUTUP}

\section{E.1 Simpulan}

Penelitian ini bertujuan untuk mengetahui dan menganalisis faktor-faktor yang mempengaruhi kemauan membayar pajak dengan kesadaran membayar pajak sebagai variabel intervening. Berdasarkan hasil penelitian yang telah dilakukan dapat diambil kesimpulan sebagai berikut:

1. Pengetahuan dan pemahaman tentang peraturan perpajakan dapat berpengaruh langsung dan dapat pula berpengaruh tidak langsung terhadap kemauan membayar pajak melalui kesadaran membayar pajak.

2. Kualitas pelayanan pajak dapat berpegaruh langsung dan dapat pula berpegaruh tidak langsung terhadap kemauan membayar pajak melalui kesadaran membayar pajak.

3. Persepsi yang baik atas efektivitas sistem perpajakan dapat berpengaruh langsung maupun tidak langsung terhadap kemauan membayar pajak melalui kesadaran membayar pajak.

4. Tingkat kepercayaan terhadap sistem pemerintahan dan hukum tidak berpengaruh secara langsung terhadap kemauan membayar pajak.

5. Namun tingkat kepercayaan dapat berpegaruh secara tidak langsung, sehingga kesadaran membayar pajak dapat memediasi hubungan antara tingkat kepercayaan terhadap pemerintahan dan hukum terhadap kemauan membayar pajak. 


\section{E.2 Saran}

Berdasarkan kesimpulan yang telah diuraikan, maka dapat disarankan hal-hal sebagai berikut:

1. Untuk penelitian selanjutnya diharapkan dapat menambah variabel lain yang dapat mempengaruhi kemauan membayar pajak dengan kesadaran membayar pajak sebagai variabel intervening. Penelitian selanjutnya dapat juga memperluas wilayah sampel penelitian, bukan hanya di Kota Ternate tetapi di daerahdaerah lainnya, sehingga hasil penelitian memiliki daya generalisasi yang lebih kuat. Selain itu, peneliti selanjutnya dapat menambahkan teknik wawancara atau pertanyaan lisan dalam metode pengumpulan data.

2. Direktorat Jenderal Pajak perlu secara berkala mengadakan acara yang mendidik serta menghibur masyarakat agar memiliki kesadaran untuk membayar pajak. Sosialisasi di acara tertentu dengan cara mengundang tokoh yang disegani oleh kalangan profesional tertentu. Upaya pelatihan atau sosialisasi perpajakan dapat menambah pengetahuan dan pemahaman terhadap peraturan perpajakan, meningkatkan persepsi yang baik dan meningkatkan kepercayaan diri wajib pajak yang dapat membantu meningkatkan kemauan membayar pajak. Melalui tingkat kepercayaan dan pengetahuan pajak yang cukup memungkinkan wajib pajak akan menjadi patuh dalam pemenuhan kewajiban perpajakan seperti sadar mendaftarkan diri untuk memperoleh NPWP.

3. Bagi wajib pajak diharapkan mengikuti penyuluhan atau sosialisasi yang diadakan oleh Direktorat Jendral Pajak mengenai perhitungan, pembayaran dan pelaporan pajak terutang. Selain itu, wajib pajak hendaknya lebih membuka wawasan dan merubah pola pikir bahwa tidak semua aparat melakukan kecurangan dalam hal perpajakan sehingga kemauan akan membayar pajak di Kota Ternate dapat dibangun.

\section{DAFTAR PUSTAKA}

Anangga, Septian. 2012. Studi Empiris Pada Penggunaan Aplikasi Pajak: Integrasi Theory of Planned Behavior dan Technolgy Acceptance Model. Skripsi. Semarang. Unviersitas Diponegoro.

Effendi, Miftahuddin dan Muhammad Abdul Aris. 2014. Analisis Faktor-Faktor Yang Mempengaruhi Kepatuhan Wajib Pajak Dalam Pemenuhan Kewajiban Perpajakannya (Studi Empiris Pada Wajib Pajak Orang Pribadi Yang Terdaftar Di Kantor Pelayanan Pajak Pratama Surakarta). Program Studi Akuntansi Universitas Muhammadiyah Surakarta.

Fikriningrum, Winda Kurnia dan Muchamad Syafruddin. 2012. Analisis Faktor-Faktor Yang Mempengaruhi Wajib Pajak Orang Pribadi Dalam Memenuhi Kewajiban Membayar Pajak (Studi Kasus Pada Kantor Pelayanan Pajak Pratama Semarang Candisari). Jurusan Akuntansi Fakultas Ekonomika dan Bisnis. Universitas Diponegoro.

Fitryani, Diniyah Nuzul. 2014. Pengaruh Kesadaran, Pemahaman, Persepsi, Tingkat Kepercayaan dan Kualitas Pelayanan Terhadap Kemauan Membayar Pajak. Skripsi. Universitas Pembangunan Nasional Veteran Yogyakarta.

Ghozali, Imam. 2013. Aplikasi Analisis Multivariate dengan Program SPSS, Edisi keempat, 
Badan Penerbit Universitas Diponegoro (BPUD), Semarang.

Handayani et al. 2012. FaktorFaktor yang Mempengaruhi Kemauan Membayar Pajak Wajib Pajak Orang Pribadi yang Melakukan Pekerjaan Bebas. Makalah Simposium Nasional Akuntansi.

Hardiningsih, Pancawati. 2011. Faktor-Faktor yang Mempengaruhi Kemauan Membayar Pajak. Universitas Stikubank.

Herry, Purwono. 2010. Dasar-Dasar Perpajakan \& Akuntansi Pajak. Jakarta: Erlangga.

Indrawan, Daud. 2014. Pengaruh Pengetahuan dan Pemahaman, Efektivitas Sistem Perpajakan dan Pelayanan Fiskus Terhadap Kemauan Membayar Pajak Dengan Kesadaran Membayar Pajak Sebagai Variabel Intervening. (Studi Empiris pada KPP Pratama Bangkinang). Jurusan Akuntansi Fakultas Ekonomi Universitas Riau.

Jatmiko, Agus Nugroho. 2006. Pengaruh Sikap Wajib Pajak pada Pelaksanaan Sanksi Denda, Pelayanan Fiskus dan Kesadaran Perpajakan Terhadap Kepatuhan Wajib Pajak (Studi Empiris terhadap Wajib Pajak Orang Pribadi di Kota Semarang). Tesis, Universitas Diponegoro, Semarang.

Kuncoro, Mudrajad. 2013. Metode Riset untuk Bisnis dan Ekonomi. Edisi keempat. Penerbit PT Erlangga, Jakarta

Leo, Sutanto. 2013. Kiat Jitu Menulis Skripsi, Tesis dan Disertasi, Bandung: Erlangga.

Nugroho, Adi Rahman. 2012. Faktor-Faktor Yang Mempengaruhi Kemauan Untuk Membayar Pajak Dengan Kesadaran Membayar Pajak
Sebagai Variabel Intervening

(Studi Kasus Wajib Pajak Orang

Pribadi Yang Melakukan Pekerjaan Bebas Pada KPP Pratama Semarang Tegah Satu). Program Studi Akuntansi Universitas Diponegoro.

Pratomo, Alloysius Brian. 2014. Pengaruh Kesadaran, Pengetahuan, Persepsi, Tingkat Kepercayaan Terhadap Kemauan Membayar Pajak: Studi Kasus Pada Wajib Pajak Pribadi di KPP Pratama Semarang Timur.

Resmi, Siti. 2011. Perpajakan: Teori dan Kasus. Edisi kelima. Jakarta: Salemba Empat.

Setyawati, Eka. 2013. FaktorFaktor Yang Mempengaruhi Kemauan Untuk Membayar Pajak Orang Pribadi Yang Melakukan Pekerjaan Bebas. Skripsi. Universitas Negeri Syarif Hidayatullah Jakarta.

Sugiyono, 2010. Metode Penelitian Bisnis. Alfabeta: Bandung.

Suhendri, Diyat. 2015. Pengaruh Pengetahuan, Tarif Pajak dan Sanksi Pajak Terhadap Kepatuhan Wajib Pajak Orang Pribadi Yang Melakukan Kegiatan Usaha Dan Pekerjaan Bebas Di Kota Padang (Studi Empiris Pada KPP Pratama Kota Padang). Program Studi Akuntansi Universitas Negeri Padang.

Susanto, Herry. 2012. Membangun Kesadaran dan Kepedulian Sukarela Wajib Pajak.

Syahri, Arfin. 2014. Faktor-Faktor Yang Mempengaruhi Kemauan Untuk Membayar Pajak Dengan Kesadaran Membayar Pajak Sebagai Variabel Intervening (Studi Empiris Wajib Pajak Orang Pribadi Yang Melakukan Pekerjaan Bebas Yang Terdaftar Di KPP Pratama Payakumbuh). Jurusan Akuntansi Fakultas 
Ekonomi Universitas Bung Hatta.

Tatiana, Vanessa Rantung dan Priyo Hari. 2009. Dampak Program Sunset Policy Terhadap Faktor-Faktor Yang Mempengaruhi Kemauan Untuk Membayar Pajak". Proceeding Simposium Nasional XI. Pontianak.

Undang-Undang No. 28 Tahun 2007 tentang Ketentuan Umum dan Tata Cara Perpajakan
Undang-Undang No. 16 Tahun 2009 tentang Perubahan Keempat Atas Undang-Undang No. 6 Tahun 1983 Tentang Ketentuan Umum Perpajakan

Widayati dan Nurlis. 2010. FaktorFaktor Yang Mempengaruhi Untuk Membayar Pajak Wajib Pajak Orang Pribadi Yang Melakukan Pekerjaan Bebas (Studi Kasus Pada KPP Pratama Gambir Tiga). Proceeding Simposium Nasional Akuntansi XII. Purwokerto. 